\title{
A consistent data set of Antarctic ice sheet topography, cavity geometry, and global bathymetry
}

\author{
R. Timmermann ${ }^{1}$, A. Le Brocq ${ }^{2}$, T. Deen ${ }^{3}$, E. Domack ${ }^{4}$, P. Dutrieux ${ }^{3}$, B. Galton-Fenzi ${ }^{5}$, H. Hellmer ${ }^{1}$, \\ A. Humbert ${ }^{6}$, D. Jansen ${ }^{7}$, A. Jenkins ${ }^{3}$, A. Lambrecht ${ }^{8}$, K. Makinson ${ }^{3}$, F. Niederjasper ${ }^{1}$, F. Nitsche ${ }^{9}$, \\ O. A. Nøst ${ }^{10}$, L. H. Smedsrud ${ }^{11}$, and W. H. F. Smith ${ }^{12}$ \\ ${ }^{1}$ Alfred Wegener Institute for Polar and Marine Research, Bremerhaven, Germany \\ ${ }^{2}$ University of Exeter, Exter, UK \\ ${ }^{3}$ British Antarctic Survey, Cambridge, UK \\ ${ }^{4}$ Hamilton College, Clinton, NY, USA \\ ${ }^{5}$ University of Tasmania, Hobart, Tasmania \\ ${ }^{6}$ KlimaCampus, University of Hamburg, Hamburg, Germany \\ ${ }^{7}$ Swansea University, Swansea, UK \\ ${ }^{8}$ University Innsbruck, Innsbruck, Austria \\ ${ }^{9}$ Lamont-Doherty Earth Observatory, Columbia University, Palisades, NY, USA \\ ${ }^{10}$ Norwegian Polar Institute, Troms $\varnothing$, Norway \\ ${ }^{11}$ Bjerknes Centre for Climate Research, Bergen, Norway \\ ${ }^{12}$ Laboratory for Satellite Altimetry, NOAA NESDIS, Silver Spring, MD, USA
}

Received: 21 July 2010 - Published in Earth Syst. Sci. Data Discuss.: 29 July 2010

Revised: 4 November 2010 - Accepted: 13 November 2010 - Published: 22 December 2010

\begin{abstract}
Sub-ice shelf circulation and freezing/melting rates in ocean general circulation models depend critically on an accurate and consistent representation of cavity geometry. Existing global or pan-Antarctic topography data sets have turned out to contain various inconsistencies and inaccuracies. The goal of this work is to compile independent regional surveys and maps into a global data set. We use the S-2004 global 1-min bathymetry as the backbone and add an improved version of the BEDMAP topography (ALBMAP bedrock topography) for an area that roughly coincides with the Antarctic continental shelf. The position of the merging line is individually chosen in different sectors in order to capture the best of both data sets. High-resolution gridded data for ice shelf topography and cavity geometry of the Amery, Fimbul, FilchnerRonne, Larsen C and George VI Ice Shelves, and for Pine Island Glacier are carefully merged into the ambient ice and ocean topographies. Multibeam survey data for bathymetry in the former Larsen B cavity and the southeastern Bellingshausen Sea have been obtained from the data centers of Alfred Wegener Institute (AWI), British Antarctic Survey (BAS) and Lamont-Doherty Earth Observatory (LDEO), gridded, and blended into the existing bathymetry map. The resulting global 1-min Refined Topography data set (RTopo-1) contains selfconsistent maps for upper and lower ice surface heights, bedrock topography, and surface type (open ocean, grounded ice, floating ice, bare land surface). The data set is available in NetCDF format from the PANGAEA database at doi:10.1594/pangaea.741917.
\end{abstract}




\section{Introduction}

Heat and salt fluxes at the base of any ice shelf, the properties of water masses within the cavity, and the exchange with the open ocean in numerical simulations strongly depend on an accurate and consistent representation of ice-shelf draft and sub-ice bathymetry. Early attempts to quantify the contribution of Ice Shelf Water to the Southern Ocean's hydrography (e.g. Hellmer and Jacobs, 1995; Beckmann et al., 1999; Timmermann et al., 2001; Assmann et al., 2003) had to admit significant uncertainties due to partly crude assumptions about the geometry of ice shelf cavities. Local or regional simulations of individual cavities and the adjacent seas were able to use more detailed data sets but suffered from uncertainties arising from the choice of open or closed boundary conditions (e.g. Gerdes et al., 1999; Grosfeld et al., 2001; Williams et al., 2001; Thoma et al., 2006; Dinniman et al., 2007) and had no possibility to investigate larger-scale impacts and feedbacks.

Melting of glaciers, ice caps and ice sheets contributes to changes of the global sea level. Therefore, an estimate of the rate of ice mass loss from the Antarctic ice sheet is an important component in the IPCC's Fifth Assessment Report. Given that most of the Antarctic ice sheet drains into floating glaciers or ice shelves, model estimates of sub-ice shelf melting rates are crucial to obtain a reliable estimate of the southern hemisphere's ice mass budget. In order to reduce uncertainties for high-resolution simulations of the coupled ocean-sea ice-ice shelf system in circumpolar or global ocean general circulation models, we compiled consistent maps for Antarctic ice sheet/shelf topography and global ocean bathymetry. These maps combine available gridded data with independent high-resolution data sets and original multibeam echosounder surveys. To preserve as much as possible information from the source data sets and to ensure an easy interpolation to any model grid, we chose a resolution of $1 \mathrm{~min}$ in zonal and meridional direction, although we are aware that large parts of the available information in high latitudes is less detailed than this grid spacing might suggest.

In this paper, we present the data sets used, discuss their spatial coverage and the preprocessing applied, the strategies followed for merging data sets, and the resulting maps of ice and bedrock topography. In contrast to the activities towards an International Bathymetric Chart of the Southern Ocean (IBCSO) (e.g., Schenke and Ott, 2009), our main goal is not a remapping of bathymetric data in the region south of $50^{\circ} \mathrm{S}$, but a consistent representation of Antarctic ice sheet/shelf topography and global bathymetry in a data set that contains enough detail for a wide range of regional and larger-scale studies. The main target group includes, but is not restricted to ocean modellers who aim at a realistic representation of Southern Ocean ice shelf processes in ocean general circulation models.

\section{Data sets and processing}

\subsection{Overview}

The RTopo-1 data set (see Figs. 1 and 2 for an overview) comprises global 1-min fields for

- bedrock topography (ocean bathymetry; surface topography of continents; bedrock topography under ice sheets/shelves)

- surface elevation (upper ice surface height for Antarctic ice sheet/shelves; bedrock elevation for ice-free continent; zero for ocean)

- ice base topography for the Antarctic ice sheet/ice shelf system (ice draft for ice shelves; zero in the absence of ice)

- masks to identify open ocean, ice sheet, ice shelf, and bare land surface

- locations of coast and grounding lines (consistent with mask) for easy plotting

For ice-free land surface, the bedrock topography and surface elevation maps are identical. Naturally, bedrock topography and ice base topography are equal for grounded ice. Ice not connected to the Antarctic ice sheet, including glaciers on subantarctic islands and the Greenland ice sheet, is not covered in our data set; these areas are labeled as bare land surface with the surface elevation preserved.

Note that in the following we use the term "ice shelf topography" for a consistent combination of ice top and bottom surface heights. The term "cavity geometry" refers to a compilation of ice-shelf draft and sub-ice (cavity) bathymetry.

\subsection{Data sources}

\subsubsection{World Ocean bathymetry}

The nucleus of RTopo-1 is the S-2004 1-minute digital terrain model (Marks and Smith, 2006), which is a combination of the gravimetry-based Smith and Sandwell (1997) map with the General Bathymetric Chart of the Oceans (GEBCO) One Minute Grid. GEBCO has been interpolated from digitized contours derived from ship-based echo-soundings and is therefore artificially smooth in many places. The two products were combined using GEBCO at locations poleward of $72^{\circ}$ latitude or shallower than $200 \mathrm{~m}$ depth (and on land), and Smith and Sandwell (1997) equatorward of $70^{\circ}$ and deeper than $1000 \mathrm{~m}$, with a smooth blending for areas in between. The result represents continental bedrock topography and bathymetry for most of the World Ocean with an impressive amount of detail. 


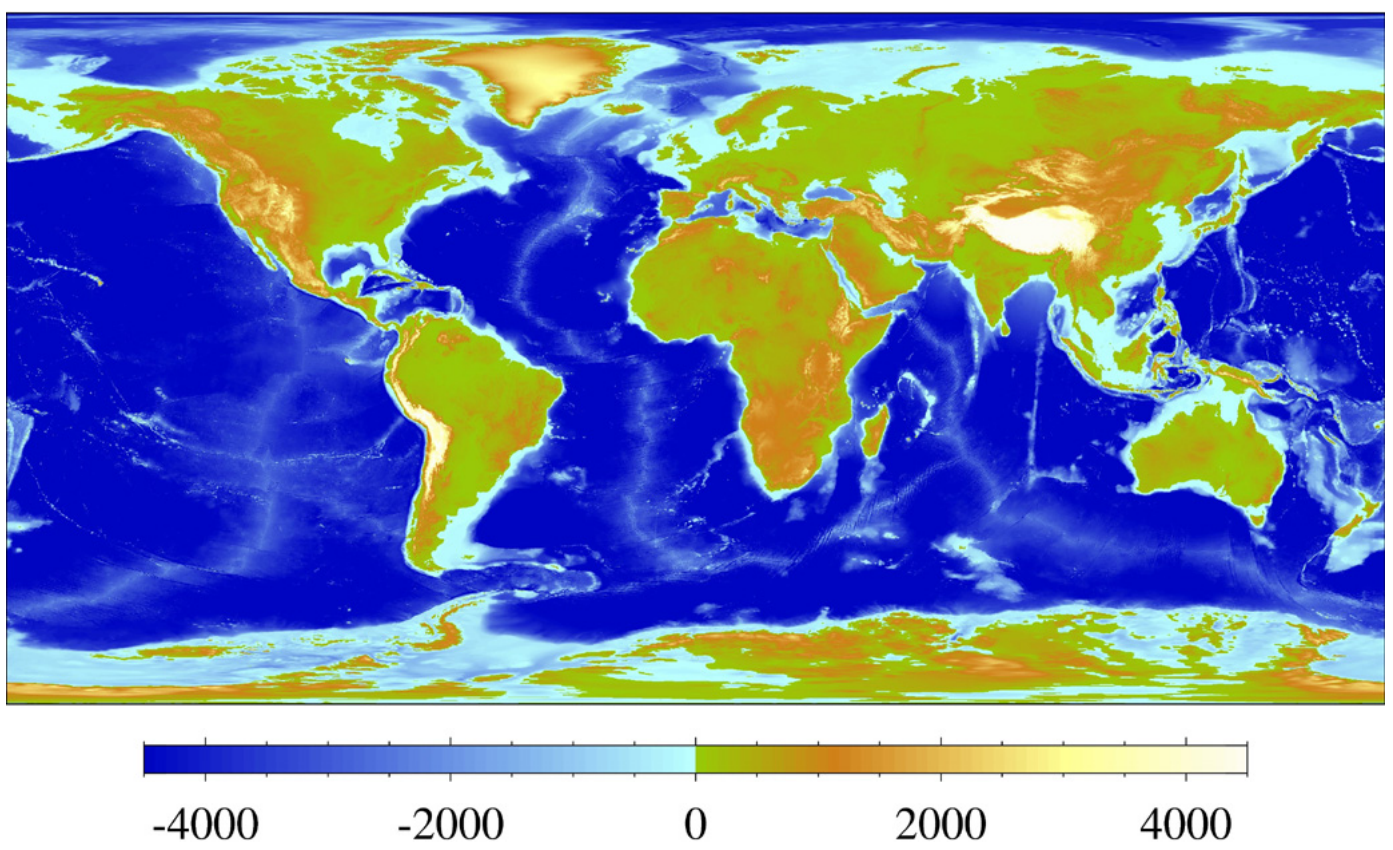

Figure 1. RTopo-1 global bedrock topography. On continents outside Antarctica, this represents the topography of the solid surface (including bottom of lakes, surface elevation of glaciers and continental ice caps) and mirrors the S-2004 data set.

For the continental shelf regions of the Southern Ocean, however, where satellite gravity data are not available, many uncertainties remain. Ice shelves are not represented in S2004 at all; instead they appear as areas with zero surface height. For the Antarctic continent, S-2004 contains the (ice) surface elevation, but not the bedrock topography.

We therefore use the S-2004 digital terrain model as the global backbone bathymetry outside the immediate vicinity of Antarctica. We keep lakes and other features with a surface height below mean sea level and no connection to the world ocean, but mark them as continent in the surface type mask (see Sect. 2.3). Antarctica and most of the Antarctic continental shelf are covered by a suite of regional and local data sets (Fig. 3), which are discussed in the following sections.

\subsubsection{Antarctic ice and bedrock topographies}

Upper and lower surface elevations for the Antarctic ice sheet and some of the ice shelves (see below for those not included) and ocean bathymetry for most of the Antarctic continental shelf are based on an improved version of the BEDMAP data set that will be refered to as ALBMAP hereafter. With the BEDMAP effort (Lythe et al., 2001), original survey data collected over about 50 years were compiled into seamless digital topography models for the Antarctic continent and ice sheet. For ALBMAP, Le Brocq et al. (2010) incorporated several new data sets. Ice surface elevation for most of Antarctica has been derived from the $1 \mathrm{~km}$ digital elevation model (DEM) of Bamber et al. (2009). For the Antarc- tic Peninsula, the RAMP DEM (Liu et al., 1999) has been added. An improved representation of sub-ice shelf cavities has been achieved by using spline-based interpolation. Bedrock depth in ALBMAP has been carefully corrected (mostly increased) towards the grounding line for many ice shelves. Maybe most important, ALBMAP ensures consistency of the different maps along the grounding lines and introduces a surface type mask for grounded ice, floating ice, and open water.

Like BEDMAP, ALBMAP uses a stereographic projection, which is very convenient for studies of the Antarctic ice sheet/shelf system, but much less so for circumpolar or global ocean models. We use spherical Delauney triangulation as a basis for linear interpolation to our regular 1-min (lon, lat) grid.

To ensure a smooth continuation of bathymetry into the sub-ice shelf cavities, we merge the ALBMAP data into S2004 not strictly along the ice-shelf edge, but at a line that has been carefully adjusted to capture the best from both data sets (Fig. 3). In the East Antarctic and many other places, the transition line follows the ice shelf front or the coast line. In order to avoid the spurious signature of General Belgrano Bank, which has been reported to be only a minor rise (with an elevation of only $20 \mathrm{~m}$ above the surrounding flat bottom) by Nicholls et al. (2003), we use ALBMAP for the entire continental shelf in the southwestern Weddell Sea south of $66.15^{\circ} \mathrm{S}$ with the transition occuring between the $1000 \mathrm{~m}$ and $2000 \mathrm{~m}$ isobaths. Similar arguments apply to the choice to use ALBMAP bathymetry in the Amundsen and Ross Seas with the transition to S-2004 placed between 2000 


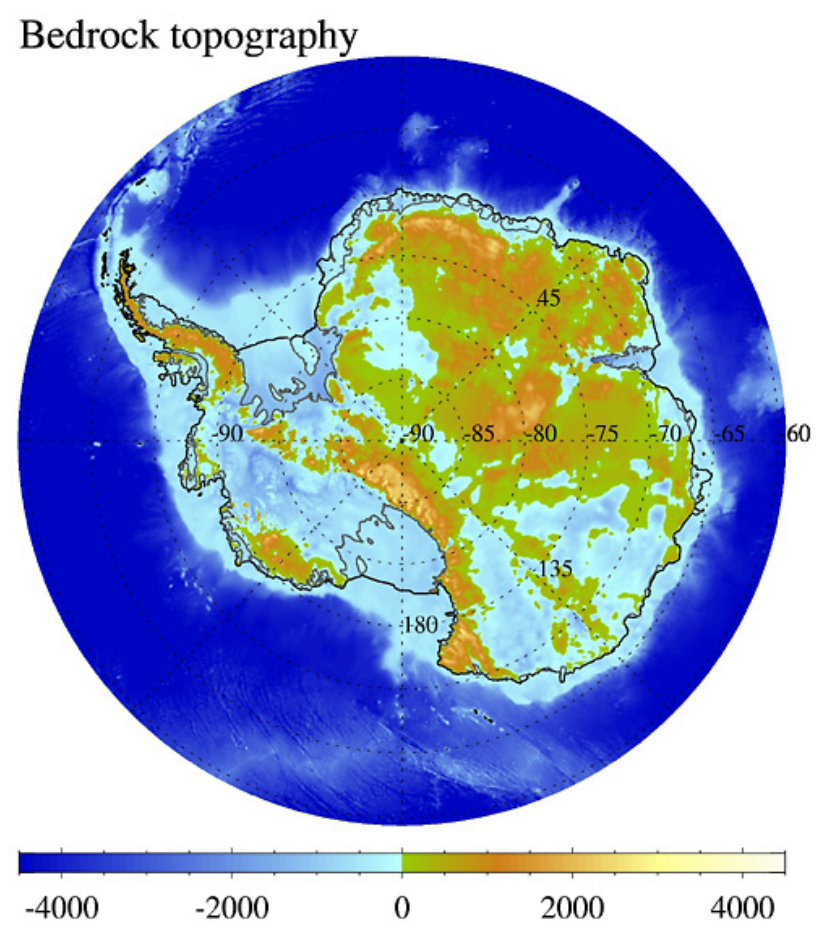

Surface elevation

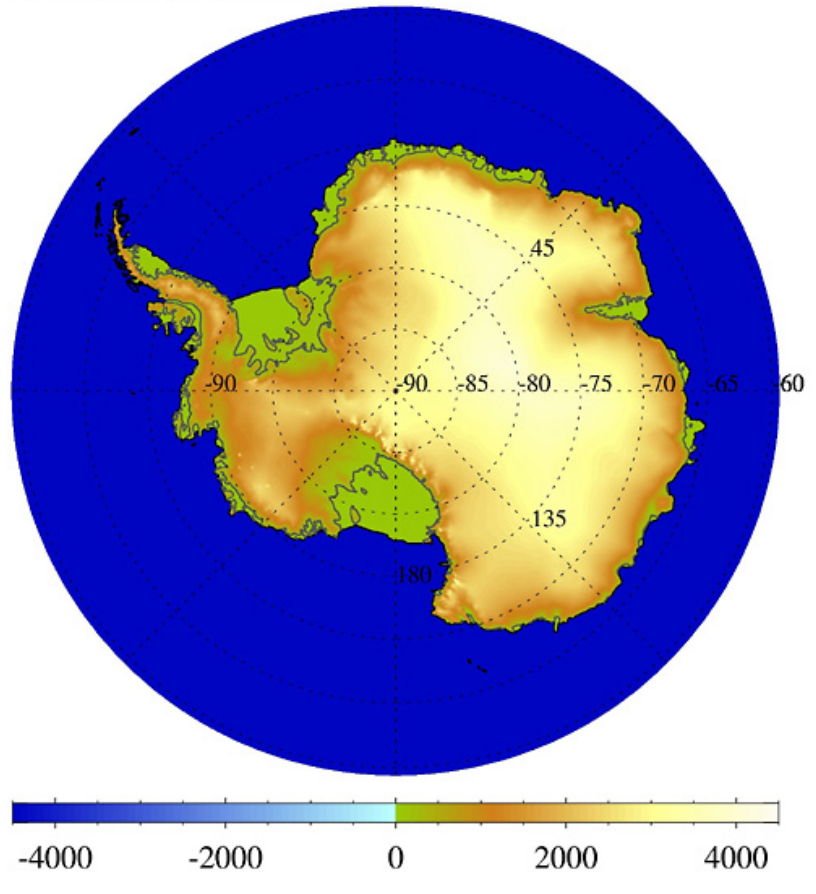

Surface type mask

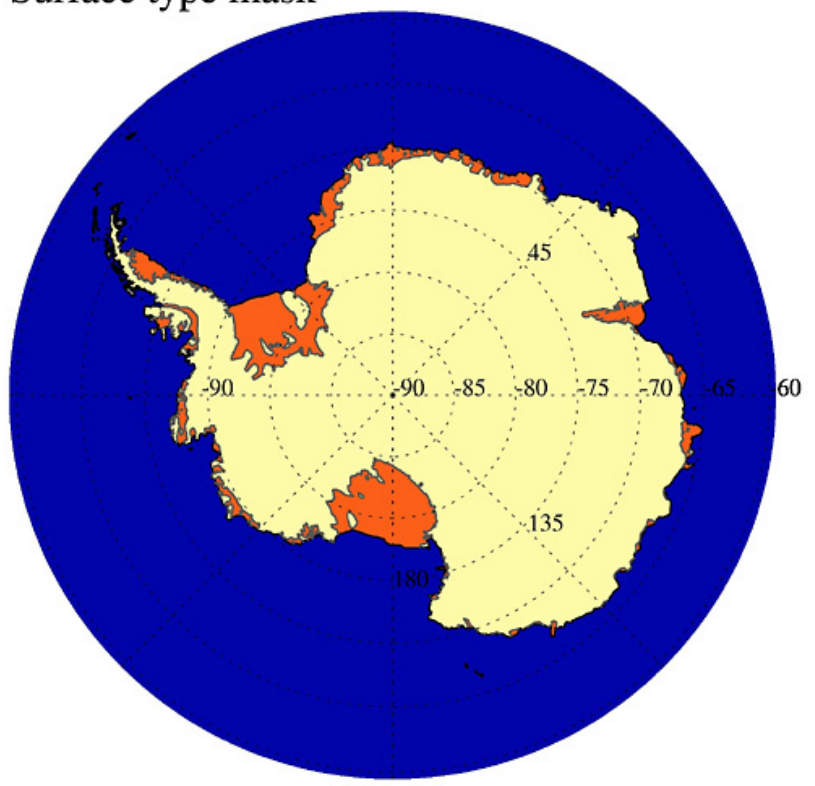

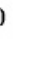

\section{Ice bottom}

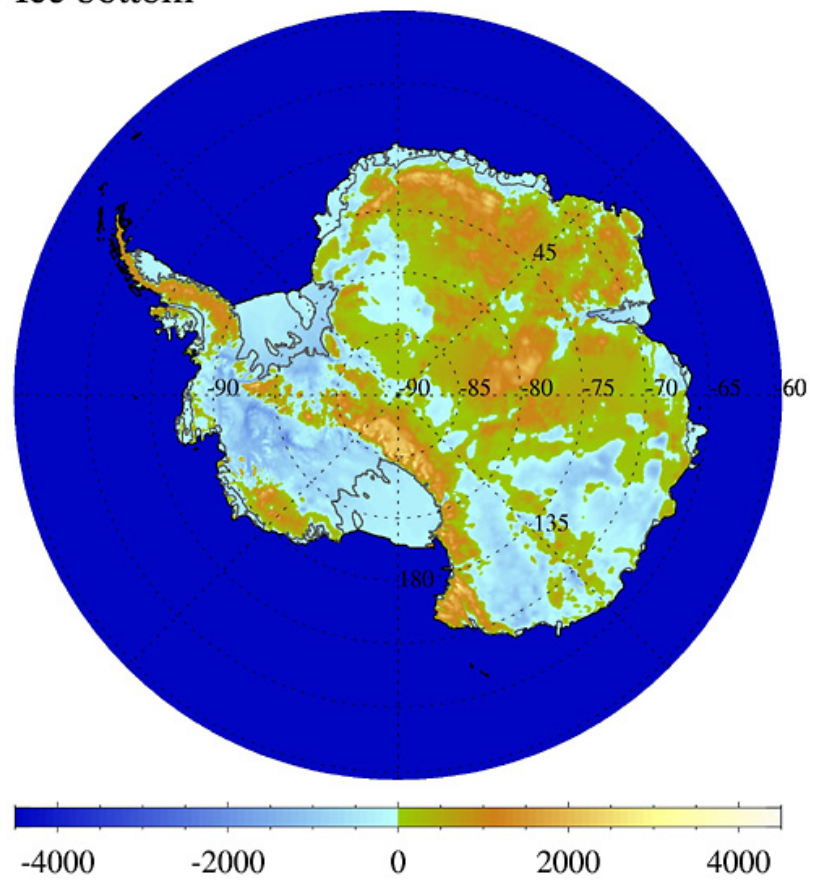



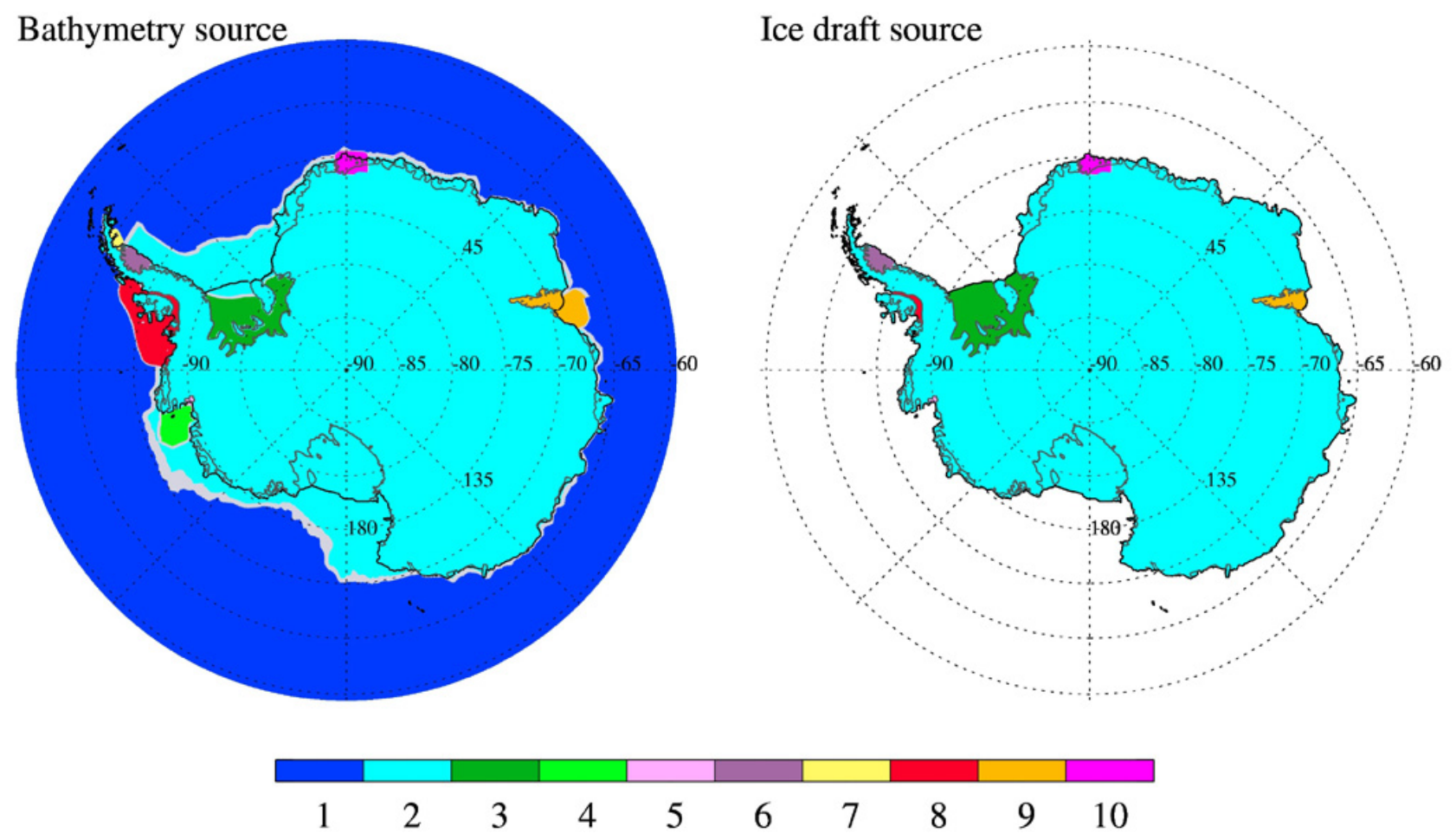

Figure 3. Data sources for ocean bathymetry (left) and ice sheet/shelf topography (right). See Table 1 for an explanation of numbers. Grey areas mark transition zones between the data sets.

and $4000 \mathrm{~m}$ water depth. Tangens hyperbolicus functions are used to ensure a smooth transition between the data sets without too much spurious blurring of gradients. The width of the transition corridor varies and can be seen in the left panel of Fig. 3.

In order to incorporate topographic information from surveys that have been conducted after the BEDMAP data set had been published, we replace ice and ocean topographies by newer, regional data sets in several places outlined in the following sections (Table 1). Again we use spherical triangulation as a basis for interpolation and tangens hyperbolicus functions of the ratio between "new" and "background" data in a data window of typically $1^{\circ}$ width for the transition between data sets. Wherever interpolation artefacts lead to inconsistencies between ice shelf draft and ocean bathymetry (resulting in negative water column thickness), we apply a minimum water column thickness of $10 \mathrm{~m}$.

\subsubsection{Filchner-Ronne Ice Shelf}

Upper and lower surface heights for Filchner-Ronne Ice Shelf and the position of the ice shelf front are derived from the ice thickness data sets of Lambrecht et al. (2007) using their Eq. (2) with the proposed densities and parameter values. Given their small-scale and transient nature, the inlets downstream from Hemmen Ice Rise are filled with interpolated values.
Bathymetry in the Filchner-Ronne Ice Shelf cavity is derived from the data set compiled by Makinson and Nicholls (1999). In order to maintain floating ice in the embayment with the inflow of Support Force Glacier, we deviate from the ALBMAP grounding line here and apply the grounding line position of Rignot and Jacobs (2002) instead, which is consistent with the maps of Makinson and Nicholls (1999) and Lambrecht et al. (2007) at this location. The ice plain to the west and the ice rumples east of Bungenstockrücken (Heidrich et al., 1992; Scambos et al., 2004) are treated as grounded ice.

Inconsistencies between the two data sets (ice thickness and bathymetry) are addressed by applying a minimum water column thickness of $10 \mathrm{~m}$ in the area of floating ice and enforcing zero water column thickness in locations with grounded ice. Given the high accuracy of the ice shelf thickness estimates (error quantified to be less than $25 \mathrm{~m}$ by the authors), we retain the Lambrecht et al. (2007) draft field and apply the corrections to the bathymetry; they are typically between 100 and $200 \mathrm{~m}$ and occur localized in a narrow band along the grounding line.

\subsubsection{Amundsen Sea ice shelves and Pine Island Glacier}

As can be seen in Fig. 3, ocean bathymetry in most of the Amundsen Sea is derived from ALBMAP, with the transition to S-2004 occuring between 2000 and $4000 \mathrm{~m}$ water depth. 
Table 1. Data sources for individual regions of the Southern Ocean, as merged into RTopo-1. Numbers in the Region column correspond to the source flag in Fig. 3

\begin{tabular}{|c|c|c|}
\hline Region & Data obtained from & Original data source(s) \\
\hline 1. World Ocean bathymetry & $\begin{array}{l}\text { S-2004 bathymetry } \\
\text { (Marks and Smith, 2006) }\end{array}$ & $\begin{array}{l}\text { GEBCO 1-min bathymetry } \\
\text { Smith and Sandwell (1997) }\end{array}$ \\
\hline $\begin{array}{l}\text { 2. Antarctic ice sheet/shelf } \\
\text { upper and lower surface heights } \\
\text { and bedrock topography }\end{array}$ & $\begin{array}{l}\text { ALBMAP-v1 } \\
\text { (Le Brocq et al., 2010) }\end{array}$ & $\begin{array}{l}\text { BEDMAP } \\
\text { AGASEA } \\
\text { Bamber et al. (2009) }\end{array}$ \\
\hline $\begin{array}{l}\text { 3. Filchner-Ronne Ice Shelf } \\
\text { - ice shelf thickness } \\
\text { - cavity bathymetry }\end{array}$ & $\begin{array}{l}\text { Lambrecht at al. (2007) } \\
\text { Makinson and Nicholls (1999) }\end{array}$ & $\begin{array}{l}\text { radar and seismic sounding } \\
\text { Vaughan et al. (1995) } \\
\text { Johnson and Smith (1997) } \\
\text { Mayer et al. (1995) }\end{array}$ \\
\hline $\begin{array}{l}\text { 4. Amundsen Sea: } \\
\text { - Pine Island Bay bathymetry }\end{array}$ & Nitsche et al. (2007) & AGASEA, ship data \\
\hline $\begin{array}{l}\text { 5. Pine Island Glacier } \\
\text { - ice draft and cavity bathymetry }\end{array}$ & Jenkins et al. (2010) & orig. AUTOSUB data \\
\hline $\begin{array}{l}\text { 6. Larsen C Ice Shelf } \\
\text { - ice shelf topography } \\
\text { - cavity bathymetry }\end{array}$ & Jansen et al. (2010) & $\begin{array}{l}\text { BEDMAP + ICESat altimetry } \\
\text { estimate using grouding line depth } \\
\text { and bathymetry at ice shelf front }\end{array}$ \\
\hline $\begin{array}{l}\text { 7. former Larsen B Ice Shelf } \\
\text { cavity bathymetry }\end{array}$ & $\begin{array}{l}\text { Domack (personal communication) } \\
\text { AWI database }\end{array}$ & $\begin{array}{l}\text { "Nathaniel B. Palmer" multibeam data } \\
\text { "Polarstern" multibeam data }\end{array}$ \\
\hline $\begin{array}{l}\text { 8. Bellingshausen Sea } \\
\text { - bathymetry } \\
\text { - George VI sub-ice bathymetry } \\
\text { - George VI ice shelf thickness }\end{array}$ & $\begin{array}{l}\text { Deen (2009) } \\
\text { Rottmann et al. (1996) } \\
\text { Potter and Paren (1985) } \\
\text { Humbert (2007) }\end{array}$ & $\begin{array}{l}\text { BAS archived multibeam data } \\
\text { "Polarstern" multibeam data } \\
\text { radar, plumb-line, seismics } \\
\text { BEDMAP + ICESat laser altimetry }\end{array}$ \\
\hline $\begin{array}{l}\text { 9. Amery Ice Shelf } \\
\text { - ice draft and cavity bathymetry }\end{array}$ & Galton-Fenzi et al. (2008) & $\begin{array}{l}\text { borehole and ship-based measurements, } \\
\text { radar, seismics, tidal modelling }\end{array}$ \\
\hline $\begin{array}{l}\text { 10. Fimbul Ice Shelf } \\
\text { - ice draft and cavity bathymetry }\end{array}$ & Smedsrud et al. (2006) & Nøst et al. (2004) \\
\hline
\end{tabular}

Open ocean bottom topography in Pine Island Bay, however, utilizes the data set from Nitsche et al. (2007), which is a combination of ship data with the "Airborne Geophysical Survey of the Amundsen Embayment" (AGASEA) and BEDMAP data sets. This data set has already been included in ALBMAP, but to preserve its fine resolution we use the original Nitsche et al. (2007) data here.

For upper and lower ice surface height and cavity bathymetry for most ice shelves in the Amundsen Sea we retain the data from ALBMAP, which in turn uses AGASEA data (Vaughan et al., 2006; Holt et al., 2006) for Thwaites Glacier Tongue, and Crosson and Dotson Ice Shelves.

An important exception is Pine Island Glacier (PIG), where the geometry of the sub-ice cavern (ice-shelf draft and sub-ice bathymetry) is interpolated from the very recent
AUTOSUB data of Jenkins et al. (2010). While BEDMAP and S-2004 do not contain any meaningful information for the sub-PIG cavity, the AUTOSUB survey revealed a trough with a depth of more than $1000 \mathrm{~m}$ at the ice front and a sill of about $300 \mathrm{~m}$ height located halfway between glacier front and grounding line (see Fig. 6 below). Water column thickness in the cavity thus varies from about $700 \mathrm{~m}$ near the glacier front to only $275 \mathrm{~m}$ at the sill, but then again increases to a maximum of $360 \mathrm{~m}$ towards the grounding line.

\subsubsection{Larsen C Ice Shelf}

For Larsen C Ice Shelf topography (surface elevation and draft) and grounding line location, we use data from Jansen et al. (2010), who combined BEDMAP data with surface 

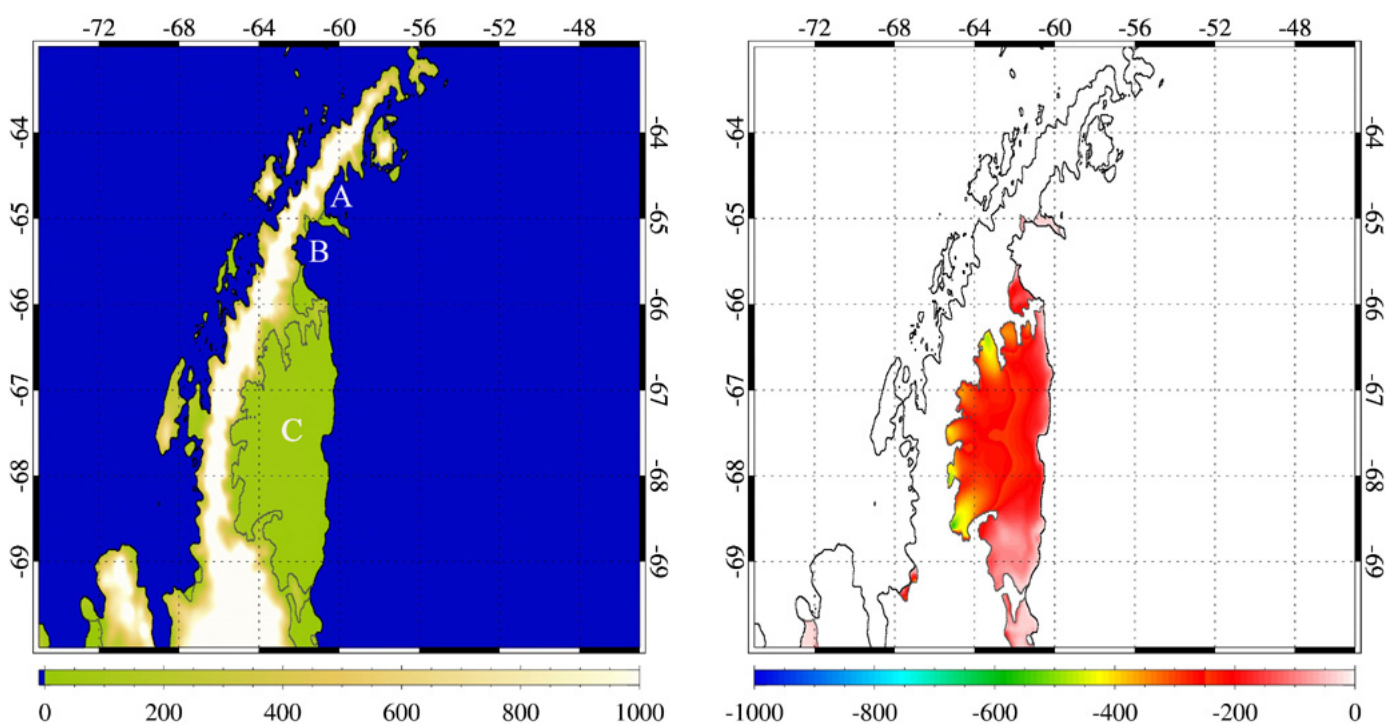

Figure 4. Surface elevation (left) and ice shelf draft (right) for the Antarctic Peninsula, including Larsen $\mathrm{C}$ ice shelf and the remnants of Larsen B ice shelf. The ice shelf front is marked with a black line, the grounding line location with a grey line. The letters $\mathrm{A} / \mathrm{B} / \mathrm{C}$ mark the (former) Larsen A, B and C Ice Shelves.

heights obtained from ICESat altimetry. The grounding line location in this data set has been picked from interferometry from the ERS-1/ERS-2 tandem mission in the north and from MODIS imagery in the south. It is a rather conservative estimate in a sense that for all areas denoted as ice shelf we can be sure to find floating ice in reality. Differences from BEDMAP draft occur mainly along the ice shelf front, where the ice is thinner now, and towards the grounding line, where the depth of the ice shelf base increases to about $550 \mathrm{~m}$ below sea level (Fig. 4).

Bottom topography in the cavity below Larsen C Ice Shelf is based on ALBMAP, but it has been modified in order to ensure a minumum water column thickness of $10 \mathrm{~m}$ near the grounding line and a gradual rise to the bottom depth found near the ice shelf front. Bathymetry now features a depth between 500 and $600 \mathrm{~m}$ under most of the ice shelf with deep troughs towards the grounding line (Fig. 5). The existence of such deep troughs in immediate vicinity to the mountains of the Antarctic Peninsula might seem doubtable at first glance; multibeam bathymetry surveys in Antarctic Sound and the former Larsen B Ice Shelf cavity (Gavahan and Domack, 2006), however, show that in fact troughs of very similar depth and horizontal scale have been carved out where ice streams eroded the ocean bottom. In any case it should be kept in mind that bathymetry in the Larsen C Ice Shelf cavity in our data set is hardly more than an educated guess.

\subsubsection{Larsen A and B Ice Shelves}

The disintegration of Larsen A and B Ice Shelves in January 1995 and February 2002, respectively, transformed the former cavities into open water embayments. For the bathymetry in this area, we combine original data from "Polarstern" cruise ANT-XXIII/8 (Pugacheva and Lott, 2008) with digitized maps of along-track multibeam data from the "Nathaniel B. Palmer" NBP0107 and NBP0603 cruise reports (E. Domack, personal communication, 2009). Again spherical triangulation is used to fill the gaps between cruise tracks (Fig. 5). The coastline of the Larsen B embayment has been corrected wherever the existence of ship tracks suggests the presence of open water instead of ice or continent.

\subsubsection{Bellingshausen Sea and George VI Ice Shelf}

For the eastern Bellingshausen Sea shelf area (i.e. the area shallower than $1000 \mathrm{~m}$ in the sector east of $90^{\circ} \mathrm{W}$ and south of $67^{\circ} \mathrm{S}$ ), bathymetry in our data set is mainly based on multibeam swath data from the BAS bathymetry database (Deen, 2009). Many of these data go back to "James Clark Ross" cruises JR104 and JR165 and have already been featured in the papers of Ó Cofaigh et al. (2005), Holland et al. (2010), and Padman et al. (2010). We add original data from R/V Polarstern cruise ANT-XI/3 (Rottmann et al., 1996) in Ronne Entrance (Fig. 6). Bottom topography underneath George VI Ice Shelf follows the sections of Potter and Paren (1985). Bathymetry in the ice shelf cavities on the western side of Alexander Island (Bach and Wilkins Ice Shelves) is retained from ALBMAP and is used as additional information for the interpolation. In contrast to the representations in BEDMAP, ALBMAP and S-2004 (Fig. 6, top row), our bathymetry data clearly indicate the existence of a 700-900 $\mathrm{m}$ deep trough that extends all the way from Marguerite Bay through George VI Sound (i.e. the cavity under George VI Ice Shelf) to Ronne Entrance. From here, further 

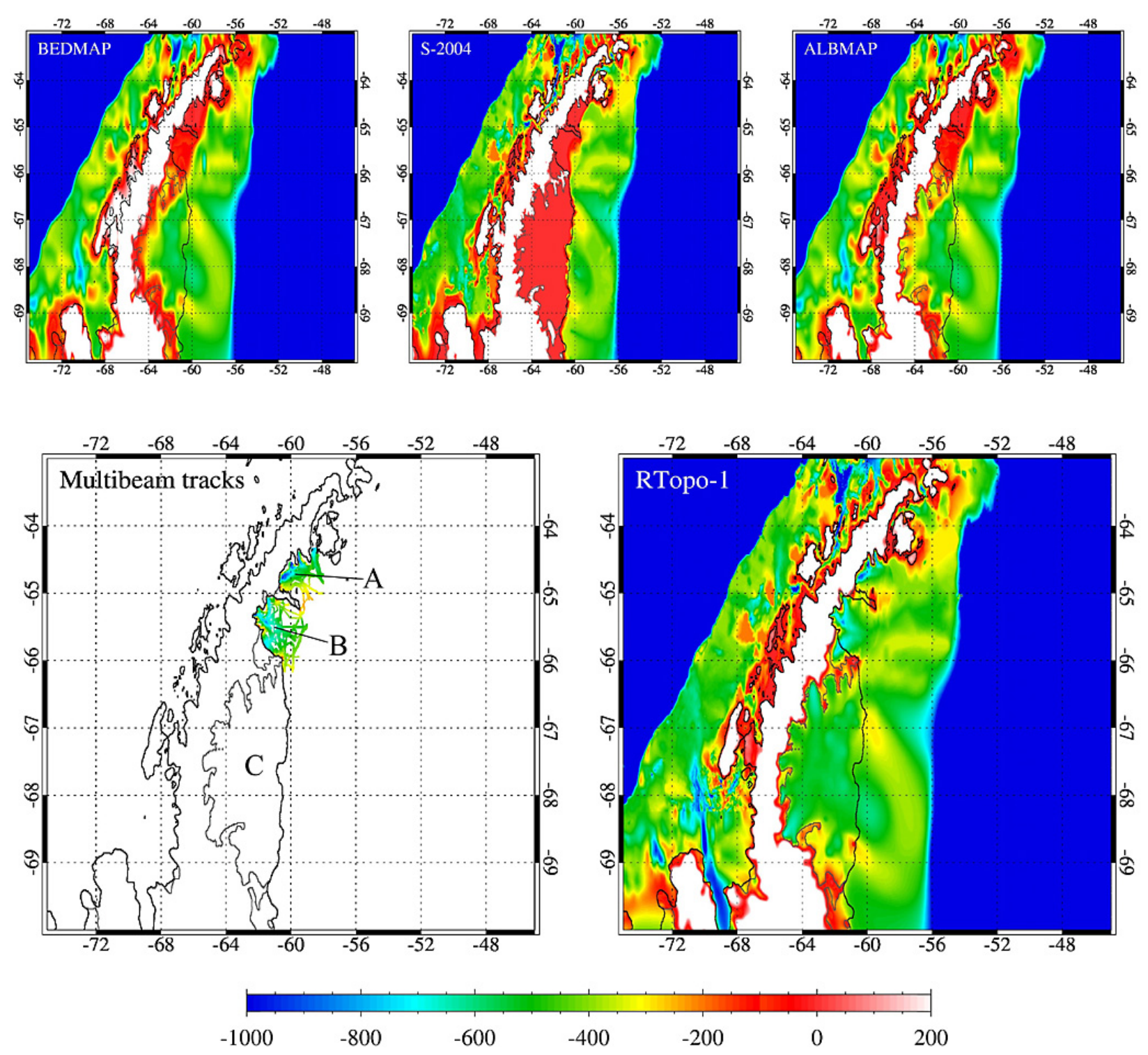

Figure 5. Different representations of bathymetry (bedrock topography) in the area of the Larsen Ice Shelves. Top row: BEDMAP (left), S-2004 (middle), and ALBMAP (right). Bottom row: Multibeam track data (left), and the RTopo-1 product (right). Ice shelf front and coastline are marked with a black line, grounding line location with a grey line. The letters A/B/C mark the (former) Larsen A, B and C Ice Shelf cavities.

channels provide connections to the continental shelf break. Note that we had to make assumptions for bathymetry in the data gap in the northern part of George VI Sound, but these are fully consistent with the Potter and Paren (1985) plumb line profile along the northern ice shelf front.

Surface elevation and draft of George VI Ice Shelf is derived from the Humbert (2007) thickness data set. Given that melt ponds occupy large parts of George VI Ice Shelf and that a distinguished firn layer is virtually absent, we convert thickness to draft assuming an ice density of $910 \mathrm{~kg} \mathrm{~m}^{-3}$ and do not apply any firn correction.

\subsubsection{Amery Ice Shelf}

For Amery Ice Shelf and the Prydz Bay region, we use the ice draft and ocean bathymetry data of Galton-Fenzi et al. (2008), who combine radar and seismic surveys, ice thickness estimates from satellite altimetry, borehole and shipbased observations, and insight obtained from tidal modelling. This data set is substantially improved over BEDMAP and ALBMAP and features a much deeper ice draft (maximum $\approx 2500 \mathrm{~m}$ ) and bathymetry (maximum bottom depth in the cavity $\approx 3000 \mathrm{~m}$ ). It also introduces five grounded-ice regions (i.e. rumples and islands), and yields substantial corrections for grounding line and ice front location. 

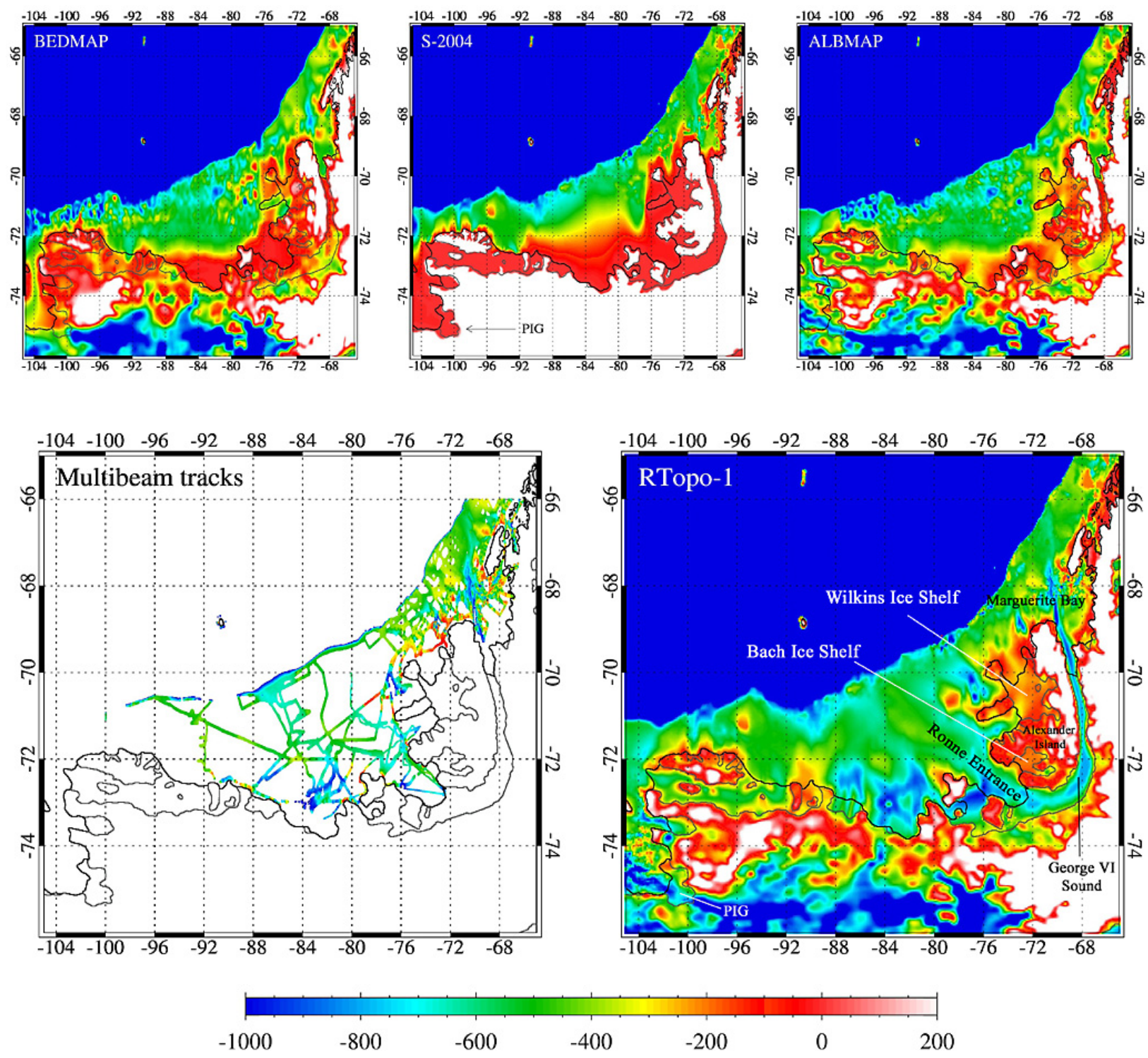

Figure 6. Different representations of bathymetry (bedrock topography) in the Bellingshausen Sea. Top row: BEDMAP (left), S-2004 (middle), and ALBMAP (right). Bottom row: Multibeam track data (left), and the RTopo-1 product (right). Note the differences for Pine Island Glacier (PIG) and George VI sub-ice bathymetries. Black line represents the coastline or ice shelf front, dark grey line the grounding line.

\subsubsection{Fimbul Ice Shelf}

For Fimbul Ice Shelf draft and sub-ice bathymetry we use the topography data set of the regional model of Smedsrud et al. (2006), who interpolated original seismic data from Nøst (2004) covering the central and outer parts of the ice shelf. For the deeper parts of the cavity towards the grounding line where no seismic data are available, ice shelf draft and bathymetry were interpolated along the flow line of the Jutulstraumen ice stream. This interpolation leads to a channel connecting the $1100 \mathrm{~m}$ deep Jutul basin with the deepest grounding line at the Fimbul ice shelf at $875 \mathrm{~m}$ depth.
We have retained the ALBMAP grounding line location here. Ice extent has been carefully reduced to match the more recent data.

\subsection{Water column thickness, masks and coastline}

As already mentioned, we provide a global mask that discriminates between grounded and floating ice, open ocean, and bare bedrock (Fig. 7). For Antarctica, the mask largely follows ALBMAP. However, coast and grounding line locations in the Larsen B Ice Shelf area are corrected based on ship tracks. Modifications based on ice front or grounding 


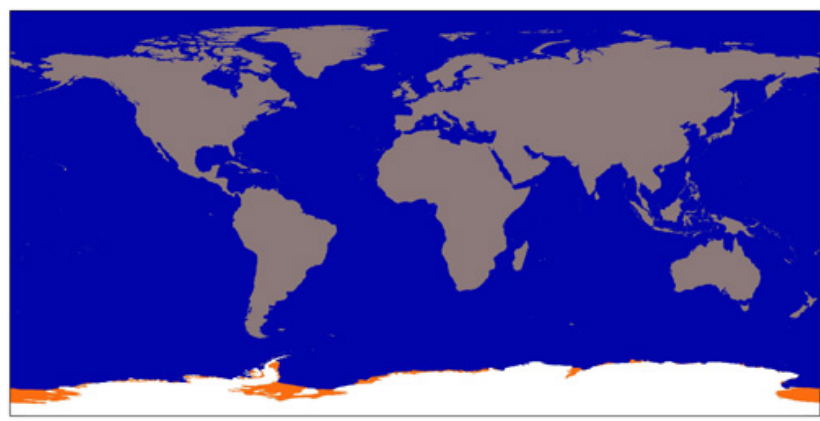

Figure 7. Global surface type mask in RTopo-1. Blue = ocean, white $=$ grounded ice, orange $=$ ice shelf, grey $=$ bare land surface.

line locations in the newly integrated local data sets are applied to Filchner-Ronne Ice Shelf (ice front; grounding line in the Support Force Glacier region), George VI Ice Shelf (ice front location in Ronne Entrance), Larsen C ice shelf (ice front and grounding line), Amery Ice Shelf (ice front, grounding line, ice rumples), and Fimbul Ice Shelf (ice front). Ice caps not connected to the Antarctic ice sheet (which at the resolution of the ALBMAP data set exist on the islands close to the Antarctic Peninsula, but not on the mainland of Antarctica) have been removed from the mask and are now classified as bedrock. Ice surface height in these cases has been adopted as the bedrock surface height. Subglacial lakes are ignored; bedrock elevation is assumed to be identical to the ice bottom surface height here.

While lakes and enclosed seas outside Antarctica are still present in the bathymetry data set (adopted from S-2004), they are marked as "bare ground" in the mask. Using the topography map(s) together with the mask thus allows for an easy generation of global or regional ocean model grids without the need to manually remove features with a topography below mean sea level and no connection to the world ocean.

Water column thickness (Fig. 8), which is needed, e.g., for the generation of ocean model grids with a terrain-following vertical coordinate, can be computed as the difference between ice bottom surface height (which contains the ice draft for ice shelves and is zero in the open ocean) and ocean bedrock topography (bathymetry). Locations of nonzero entries in the resulting field are consistent with the area denoted as "ocean" in the mask.

Last but not least, the data set contains position data for coast and grounding lines that are consistent with the mask and all other (data) fields. These can be used for an easy and overlap-free plotting of maps in any desired projection (and have been used for all the maps in this paper).

\subsection{Error estimates}

For a synthesis of several data sets of very different nature, errors are hard to quantify. This is partiularly true where values have been inferred from consistency arguments, e.g. near

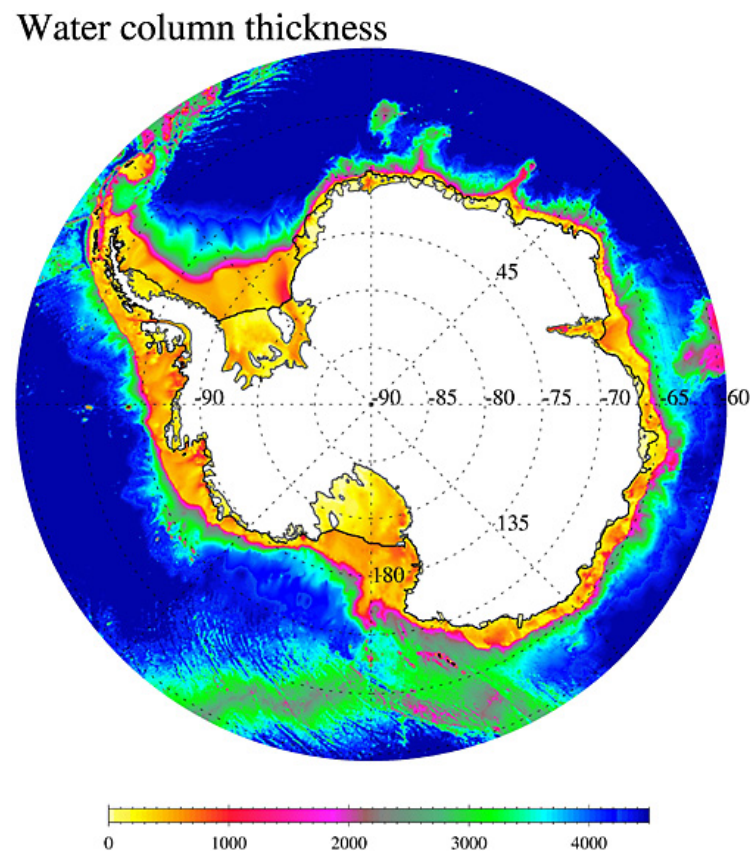

Figure 8. Water column thickness in the Southern Ocean sector of RTopo-1.

the coast or grounding lines and in the transition corridors between different data sets. Here we give an overview on error estimates provided by the authors of some of our source data sets.

\subsubsection{Ice surface height}

Griggs and Bamber (2009) used airborne altimeter data from four campaigns in Antarctica covering a wide range of surface slopes and ice sheet regions to assess the accuracy of the Bamber et al. (2009) 1-km DEM. They found that rootmean-squared differences varied from about $5 \mathrm{~m}$ in a region with gentle slopes near Ross Ice Shelf to about $35 \mathrm{~m}$ at the Antarctic Peninsula where surface slopes are steep and the across-track spacing of the satellite data is relatively large. Errors ranged from typically $1 \mathrm{~m}$ over the ice shelves to 2 $6 \mathrm{~m}$ for the majority of the grounded ice sheet. In the steeply sloping margins along the Peninsula and mountain ranges the error was estimated to be several tens of metres. Given that this data set is one of the backbone data sets in ALBMAP, these numbers indicate a likely range for surface elevation errors in RTopo-1.

\subsubsection{Ice thickness and ice shelf draft}

Errors for topography of the lower ice surface mostly arise from errors in firn correction, ice surface errors, and deviation from the hydrostatic assumption near the grounding line. For Filchner-Ronne Ice Shelf, Lambrecht et al. (2007) quantified the thickness error to be less than $25 \mathrm{~m}$; we expect 
errors to be slightly larger for less densely surveyed ice shelves. Maps of survey tracks have been provided by Lythe et al. (2001) for the BEDMAP data set and by Holt et al. (2006) and Vaughan et al. (2006) for the AGASEA product; they give an indication for the distribution of uncertainties in the gridded data.

\subsubsection{Bathymetry}

For their gravity-based topography data set, Smith and Sandwell (1997) used a worst case scenario, i.e. a highrelief area near the Foundation Seamounts (summits less than $1000 \mathrm{~m}$ below the surface; ocean floor typically $4000 \mathrm{~m}$ deep with a 6500-m-deep trough) far away from most soundings, to compare their topography estimate to independent shipbased multibeam soundings. They found an rms difference between their estimates and the observed values of about $250 \mathrm{~m}$, which can be regarded as the upper limit for possible errors in this product. Coherency between the estimates and the observed depths was found to be high at all wavelengths greater than $25 \mathrm{~km}$, while two narrow objects may blur into one object if they are much closer than that.

For the two sectors with newly gridded bathymetry data in the Bellingshausen Sea and the Larsen A/B Ice Shelves area, the maps of ship tracks we provide in Figs. 5 and 6 may serve as an indication for actual data coverage. Along the ship tracks, accuracy is about $2 \%$ of water depth, which converts to an error between 10 and $20 \mathrm{~m}$. Between the tracks, uncertainties are of course much higher.

In contrast to this, sub-ice bathymetry for many of the ice shelves is mainly inferred from soundings near the ice front and ice thickness/draft at the grounding line; it is thus not very well constrained. This is particularly true for the Larsen C Ice Shelf cavity, but also for the smaller ice shelves in the Amundsen Sea (PIG being a prominent exception), where bathymetry under the ice is largely unknown. The PIG cavity instead has been surveyed by an autonomous underwater vehicle, so that cavity geometry is accurately known along the survey tracks. Even for this small and relatively wellsurveyed ice shelf, however, the map of AUTOSUB tracks in Jenkins et al. (2010) reveals that substantial unsampled areas still remain.

\section{Summary and outlook}

We have presented a global 1-min data set for World Ocean bathymetry and Antarctic ice sheet/shelf topography that compiles high-resolution data for the Amery, Fimbul, Filchner-Ronne, Larsen C and George VI Ice Shelves, and for Pine Island Glacier into a synthesis of the S-2004 global 1-min bathymetry with a BEDMAP-derived panantarctic topography data set. Wherever maps were derived from original bathymetry surveys (namely in the Larsen A/B Ice Shelf area and the southeastern Bellingshausen Sea), we have presented data coverage and the resulting gridded fields. Next to maps for bedrock topography and the upper and lower surface heights of the Antarctic ice sheet/ice shelf system, the data set contains consistent masks for open ocean, grounded ice, floating ice, and bare land surface.

Future developments may be related to using alternative interpolation schemes to fill the data gaps in Antarctic bedrock topography maps, like for example the streamlinefollowing interpolation scheme presented by Warner and Roberts (2010). Additional contributions regarding local ice shelf/cavity geometry are very welcome and will be used to update the data set as soon as possible.

\section{Data access}

The RTopo-1 data set is available in NetCDF format in two flavours at: doi:10.1594/pangaea.741917:

1. The complete global 1-min data set has been split into two files:

- RTopo<version>_data.nc (2.8 GB file size) contains the digital maps for bedrock topography, ice bottom topography, and surface elevation.

- RTopo<version>_aux.nc (700 MB file size) contains the auxiliary maps for data sources and the surface type mask.

2. A regional subset that covers all variables for the region south of $50^{\circ} \mathrm{S}$ is available in RTopo<version> $50 \mathrm{~S}$.nc (780 MB file size).

Data sets for the location of grounding line (RTopo<version>_gl.asc, $1.7 \mathrm{MB}$ ) and coast line (RTopo<version>_coast.asc, $17.5 \mathrm{MB}$ ) are prepared in ASCII format and simply contain two columns for longitude and latitude, separated by blanks.

To enable communication in case of errors or updates, we would appreciate a notification from users of our data set.

Acknowledgements. We would like to thank Povl Abrahamsen, Mike Dinniman, Dorothea Graffe, Hannes Grobe, Klaus Grosfeld, Verena Haid, Claus-Dieter Hillenbrand, Stanley S. Jacobs, Laura Jensen, Robert D. Larter, Uta Menzel, Eric Rignot, James Smith, and David Vaughan for their rapid-response help and support. Galton-Fenzi (2008) topography data were provided by the Antarctic Climate and Ecosystems CRC. Lambrecht et al. (2007) thickness data and ALBMAP-v1 were obtained from the PANGAEA data supplements doi:10.1594/PANGAEA.615277 and doi:10.1594/PANGAEA.734145, respectively. All other digital data were received directly from the authors. Helpful comments from two anonymous reviewers are gratefully acknowledged.

This work was supported by funding to the ice2sea programme from the European Union 7th Framework Programme, grant number 226375. Ice2sea contribution number 13.

Edited by: F. Schmitt 


\section{References}

Assmann, K., Hellmer, H. H., and Beckmann, A.: Seasonal variation in circulation and water mass distribution on the Ross Sea continental shelf, Antarct. Sci., 15(1), 3-11, doi:10.1017/S0954102003001007, 2003.

Bamber, J. L., Gomez-Dans, J. L., and Griggs, J. A.: A new 1 km digital elevation model of the Antarctic derived from combined satellite radar and laser data - Part 1: Data and methods, The Cryosphere, 3, 101-111, doi:10.5194/tc-3-101-2009, 2009.

Beckmann, A., Hellmer, H. H., and Timmermann, R.: A numerical model of the Weddell Sea: Large-scale circulation and water mass distribution, J. Geophys. Res., 104(C10), 23375-23391, 1999.

Deen, T. J. (Ed.): The British Antarctic Survey Geophysics Data Portal, British Antarctic Survey, Cambridge, UK, available at: http://geoportal.nerc-bas.ac.uk/GDP, 2009.

Dinniman, M. S., Klinck, J. M., and Smith Jr., W. O.: Influence of Sea Ice Cover and Icebergs on Circulation and Water Mass Formation in a Numerical Circulation Model of the Ross Sea, Antarctica, J. Geophys. Res., 112, C11013, doi:10.1029/2006JC004036, 2007.

Domack, E., Duran, D., Leventer, A., Ishman, S., Doane, S., McCallum, S., Amblas, D., Ring, J., Gilbert, R., and Prentice, M.: Stability of the Larsen B ice shelf on the Antarctic Peninsula during the Holocene epoch, Nature, 436, 681-685, doi:10.1038/nature03908, 2005.

Galton-Fenzi, B. K., Maraldi, C., Coleman, R., and Hunter, J.: The cavity under the Amery Ice Shelf, East Antarctica, J. Glaciol., 54(188), 881-887, 2008.

Gavahan, K. and Domack, E.: Paleohistory of the Larsen Ice Shelf Phase II, Year 3, NBP0603 Multibeam End of Cruise Report, 10 pp., 2006.

Gerdes, R., Determann, J., and Grosfeld, K.: Ocean circulation beneath Filchner-Ronne-Ice-Shelf from three-dimensional model results, J. Geophys. Res., 104(C7), 15827-15842, 1999.

Griggs, J. A. and Bamber, J. L.: A new $1 \mathrm{~km}$ digital elevation model of Antarctica derived from combined radar and laser data - Part 2: Validation and error estimates, The Cryosphere, 3, 113-123, doi:10.5194/tc-3-113-2009, 2009.

Grosfeld, K., Schröder, M., Fahrbach, E., Gerdes, R., and Mackensen, A.: How iceberg calving and grounding change the circulation and hydrography in the Filchner Ice Shelf-Ocean System, J. Geophys. Res., 106(C5), 9039-9055, doi:2000JC000601, 2001.

Heidrich, B., Sievers, J., Schenke, H. W., and THIEL, M.: Digitale Topographische Datenbank Antarktis - Die Küstenregionen vom westlichen Neuschwabenland bis zum Filchner-Ronne Schelfeis interpretiert aus Satellitenbilddaten, Nachrichten aus dem Karten- und Vermessungswesen, I(107), 127-140, 1992.

Hellmer, H. H. and Jacobs, S.S.: Seasonal circulation under the eastern Ross Ice Shelf, Antarctica, J. Geophys. Res., 100(C6), 10873-10885, 1995.

Holland, P. R., Jenkins, A., and Holland, D. M.: Ice and ocean processes in the Bellingshausen Sea, Antarctica, J. Geophys. Res., 115, C05020, doi:10.1029/2008JC005219, 2010.

Holt, J. W., Blankenship, D. D., Morse, D. L., Young, D. A., Peters, M. E., Kempf, S. D., Richter, T. G., Vaughan, D. G., and Corr, H. F. J.: New boundary conditions for the West
Antarctic Ice Sheet: Subglacial topography of the Thwaites and Smith glacier catchments, Geophys. Res. Lett., 33, L09502, doi:10.1029/2005GL025561, 2006.

Humbert, A.: Numerical simulations of the ice flow dynamics of the George VI Ice Shelf, Antarctica, J. Glaciol., 53(183), 659-664, 2007.

Jansen, D., Kulessa, B, Sammonds, P. R., Luckman, A. J., King, E. C., and Glasser, N. F.: Present Stability of the Larsen C Ice Shelf, J. Glaciol., 56(198), 593-600, 2010.

Jenkins, A., Dutrieux, P., Jacobs, S. S., McPhail, S. D., Perrett, J. R., Webb, A. T., and White, D.: Observations beneath Pine Island Glacier in West Antarctica and implications for its retreat, Nat. Geosci., 3, 468-472, doi:10.1038/ngeo890, 2010.

Johnson, M. R. and Smith, A. M.: Seabed topography under the southern and western Ronne Ice Shelf, derived from seismic surveys, Antarct. Sci., 9(2), 201-208, 1997.

Lambrecht, A., Sandhäger, H., Vaughan, D. G., and Mayer, C.: New ice thickness maps of Filchner-Ronne Ice Shelf, Antarctica, with specific focus on grounding lines and marine ice, Antarct. Sci., 19(4), 521-532, doi:10.1017/S0954102007000661, 2007.

Le Brocq, A. M., Payne, A. J., and Vieli, A.: An improved Antarctic dataset for high resolution numerical ice sheet models (ALBMAP v1), Earth Syst. Sci. Data, 2, 247-260, doi:10.5194/essd-2-247-2010, 2010.

Liu, H., Jezek, K., and Li, B.: Development of an Antarctic digital elevation model by integrating cartographic and remotely sensed data: A geographic information system based approach, J. Geophys. Res., 104(B10), 23199-23213, 1999.

Lythe, M. B., Vaughan, D. G., and the BEDMAP Consortium: BEDMAP - A new ice thickness and subglacial topographic model of Antarctica, J. Geophys. Res., 106(B6), 11335-11351, 2001.

Makinson, K. and Nicholls, K. W.: Modeling tidal currents beneath Filchner-Ronne Ice Shelf and on the adjacent continental shelf: their effect on mixing and transport, J. Geophys. Res., 104(C6), 13449-13465, 1999.

Marks, K. M. and Smith, W. H. F.: An evaluation of publicly available global bathymetry grids, Mar. Geophys. Res., 27, 19-34, doi:10.1007/s11001-005-2095-4, 2006.

Mayer, C., Lambrecht, A., and Oerter, H.: Glaciological investications on the Foundation Ice Stream. Filchner Ronne Ice Shelf Programme Report No 9. H. Oerter, Bremerhaven, Germany, Alfred-Wegener-Institue for Polar and Marine Research, 57-63, 1995.

Nicholls, K. W., Padman, L., Schröder, M., Woodgate, R. A., Jenkins, A., and Østerhus, S.: Water mass modification over the continental shelf north of Ronne Ice Shelf, Antarctica, J. Geophys. Res, 108(C8), 3260, doi:10.1029/2002JC001713, 2003.

Nitsche, F. O., Jacobs, S., Larter, R. D., and Gohl, K.: Bathymetry of the Amundsen Sea Continental Shelf: Implications for Geology, Oceanography, and Glaciology, Geochem. Geophy. Geosy., 8, Q10009, doi:10.1029/2007GC001694, 2007.

Nøst, O. A.: Measurements of ice thickness and seabed topography at Fimbul Ice Shelf, Dronning Maud Land, Antarctica, J. Geophys. Res., 109, C10010, doi:10.1029/2004JC002277, 2004.

Ó Cofaigh, C., Larter, R. D., Dowdeswell, J.A., Hillenbrand, C.-D., Pudsey, C. J., Evans, J., and Morris, P.: Flow of the West Antarctic Ice Sheet on the continental margin of the Bellingshausen Sea at the Last Glacial Maximum, J. Geophys. Res., 110, B11103, 
doi:10.1029/2005JB003619, 2005.

Padman, L., Costa, D. P., Bolmer, S. T., Goebel, M. E., Huckstadt, L. A., Jenkins, A., McDonald, B. I., and Shoosmith, D. R.: Seals map bathymetry of the Antarctic continental shelf, Geophys. Res. Lett., 37, L21601, doi:10.1029/2010GL044921, 2010.

Potter, J. R. and Paren, J. G.: Interaction between ice shelf and ocean in George VI Sound, Antarctica, in: Oceanology of the Antarctic Continental Shelf, edited by: Jacobs, S. S., Antarctic Research Series, 43, 35-58, American Geophysical Union, 1985.

Pugacheva, E. and Lott, J.-H.: Bathymetry, in: The expedition ANTARKTIS-XXIII/8 of the research vessel "Polarstern" in 2006/2007, edited by: Gutt, J., Berichte zur Polar- und Meeresforschung, 569, 153 pp., 2008.

Rignot, E. and Jabocs, S. S.: Rapid bottom melting widespread near Antarctic ice sheet grounding lines, Science, 296, 2020-2023, 2002.

Rottmann, E., Grünwald, T., Niederjasper, F., and Weigelt, M.: Bathymetrie. In: The Expedition Antarktis-XI/3 of RV "Polarstern" in 1994, Reports on Polar Research, 188, 22-28, AWI, Bremerhaven, 1996.

Scambos, T., Bohlander, J., Raup, B., and Haran, T.: Glaciological characteristics of Institute Ice Stream using remote sensing, Antarct. Sci., 16(2), 205-213, doi:10.1017/S0954102004001919, 2004.

Schenke, H. W. and Ott, N.: Report on the International Bathymetric Chart of the Southern Ocean (IBCSO), IHO Hydrographic Committee on Antarctica 9th Meeting, Simon's Town, 12-14 October 2009, available at: http://www.ibcso.org/history.html, 2009.

Smedsrud, L. H., Jenkins, A., Holland, D. M., and Nøst, O. A.: Modeling ocean processes below Fimbulisen, Antarctica, J. Geophys. Res., 111, C01007, doi:10.1029/2005JC002915, 2006.
Smith, W. H. F. and Sandwell, D. T.: Global sea floor topography from satellite altimetry and ship depth soundings, Science, 277, 1956-1962, 1997.

Thoma, M., Grosfeld, K., and Lange, M. A.: The impact of the Eastern Weddell Ice Shelves on water masses in the eastern Weddell Sea, J. Geophys. Res., 111, C12010, doi:10.1029/2005JC003212, 2006.

Timmermann, R., Beckmann, A., and Hellmer, H. H.: The role of sea ice in the fresh water budget of the Weddell Sea, Ann. Glaciol., 33 419-424, 2001.

Vaughan, D. G., Sievers, J., Doake, C. S. M., Hinze, H., Mantripp, D. R., Pozdeev, V. S., Sandhäger, H., Schenke, H. W., Solheim, A., and Thyssen, F.: Subglacial and Seabed Topography, Ice Thickness and Water Columm Thickness in the Vicinity of Filchner-Ronne-Schelfseis, Antarctica, Polarforschung, 64, 2, 75-88, hdl:10013/epic.29728.d001, 1995.

Vaughan, D. G., Corr, H. F. J., Ferraccioli, F., Frearson, N., O’Hare, A., Mach, D., Holt, J., Blankenship, D., Morse, D., and Young, D. A.: New boundary conditions for the West Antarctic ice sheet: subglacial topography beneath Pine Island Glacier, Geophys. Res. Lett., 33, L09501, doi:10.1029/2005GL025588, 2006.

Warner, R. and Roberts, J.: Unveiling the Antarctic subglacial landscape, Geophys. Res. Abstr., 12, EGU2010-7864-2, EGU General Assembly, 2010.

Williams, M. J. M., Grosfeld, K., Warner, R., Gerdes, R., and Determann, J.: Ocean circulation and ice-ocean interaction beneath the Amery Ice Shelf, Antarctica, J. Geophys. Res., 106(C10), 22383-22399, 2001. 